\title{
Population density of Oryctes elegans Prell. (Coleoptera: Scarabaeidae) on some date palm varieties in South Baghdad Orchards
}

\author{
*Mohammed Zaidan Khalaf * Falah Hanash Naher \\ ${ }^{* *}$ Abdul -Sattar Arif Ali \\ *IPM Center, Ministry of Science and Technology, Baghdad, Iraq. \\ ${ }^{\star *}$ Coll. Agric.Al-Anbar University,Al -Anbar, Iraq. \\ Email:mzkhalaf2007@yahoo.com
}

\begin{abstract}
Laboratory and field studies were conducted to investigate the population density of Fruit stalk borer Oryctes elegans Prell in date palm orchards grown in Al-madain region about $30 \mathrm{~km}$ south of Baghdad in 2009. The susceptibility of some date palm varieties, ( Braim, Ustaomran, Zahdi, Berhee, Khadhrawi, Khastawi, and Oueedi), to borer infestation was also tested. Results indicated that the mean density for borer larvae was 5.75 individual/tree. The Brim variety showed the highest susceptibility with an average of larvae population reached to 13 individual/tree. found in the part of the tree which was under annual management for bruning and removal of old fronds used to done during March and April. As for the adult density, results obtained by solar light trap showed that the mean number for adults catch was 29 insect /trap for the period of July to October while the highest trap catch was 37 adult /trap occurred during September. Results of the morphological studies had also indicated the presence of some differences in term of width, depth, weight of frond bases. Therefore, results of this study could be of benefit for orchards owners when applying an integrated program for controlling date palm pests.
\end{abstract}

\section{INTRODUCTION}

Date palms Phoenix dactylifera (L.) are considered as one of the most economically important fruit trees in Iraq. These trees and their fruits are subjected to infestation by many serous insect pests (Al Beker1972, Al- Bahely 2004, Al-Jboory el.al.2001,BaAngood et.al.2009, Dhiab et.al. 1979 ,Hussain1974 , Martin,1968 , Zaid, A.2002) The bunch stalk borer Oryctes elegans Prell is considered as a key pest on date palm in many places of the world and a damaging levels could be found in Iraq and surrounding countries (Hussain1974, Dhiab et.al.1979). This borer had been reported as a major pest on date palm in Qatar (Al - azawi,), Oman (Élan and Tameimi.1999), Egypt, and in the causal region of Lybia (Dowson,.1982). In Iraq, the date palm borers complex such as the longhorn stem borer,Jebusaea hammerschmidti Reiche ; the bunch stalk borer,Oryctes elegans ; the frond borer,Phonabate frontalis Fahraeus are found in most date palm growing regions, however damaging infestation are usually reported in Central and the Southern Provinces(Al- Khawaga,.1999, Hussain1974, Swayir et.al.1979 ).Previous studies indicated that the borer $O$. elegans has one generation per year. Adults emergence start during March and continued till October (Ali. and AlSandouk2000, Harib.1970, Swayir et.al.1979.) and Infestation percentages may reach 80 - 90\%in some places (Al- Khawaga,1999 ).Adult insects are the damaging stage feeding on the bases of frond and bunches making a long tunnels in the tissue which are acting as a weakening and breaking factors for these parts. The opened tunnels may attract other insect pests and plant pathogens' leading to the complication of the problem (Al - Beker1972, Swayir et.al.1979) .This pest is controlled mainly by using non specific chemical pesticides. The present study was initiated to investigate the population density of Fruit stalk borer and to determine the susceptibility of some date palm varieties to infestation in order to identify the best timing and the proper control practice against this pest in date palm orchards.

\section{MATARIALS AND MATHODS}

Population density of O.elegans larvae: The field survey was conducted in Al- Madain region about 30 $\mathrm{Km}$. South of Baghdad during March and April of 2009 which was coinciding with some annual cultural practices of date palm orchards in the region (such as pruning, cutting and removing of old fronds and pollination activities).Date palm varieties included in the survey were; Brim, Oustaomran, Zahdi, Berhee, Khadhrawi, Khastawi, Oueedi, and Tebarzal. Samples were taken from the terminal part of the tree and were concentration on the lower row of dried leaves and basis of fronds. The survey was conducted as a joint action with the workers at the 
time of practicing the above mentioned cultural activities. Twenty trees representing each variety were taken randomly and borer larvae found in these trees were collected and held in separated plastic jars about $5 \mathrm{Kg}$ in capacity with some pieces of wet frond bases for feeding. These containers were labeled with information about the number of tree, variety, and number of larvae in each intended container which then were taken to laboratory to observe their development on the tissue of each variety. Information on some biological characters, surviving larvae, and any other signs were also recorded.Photographic pictures for infestation symptoms and feeding sites of larvae were taken as a record and as a reference for the purpose of this study and other studies.

Population density of O.elegans adults:Solar energy based light trap was used during the period of this study. The trap was designed and manufactured by specialist working at the Ministry of sciences and Technology (Fig.1).The trap was received in the beginning of July and was directly placed in the orchards. Examination of trap was made monthly and adults of the borer were collected and held in specific containers for farther identifications and studies. Monitoring was continued till the end of October of the same year. and the number of trapped insects and population density were calculated for each month.

Some morphological characters of frond bases for experimental date palm varieties: Samples of frond bases were taken from each of the date palm varieties, Brim, Ostaomran, Zahdi, Berhee, and Tebarzal. Five trees from each variety were taken randomly with an average of three samples per tree representing second lower row of dried leaves in order to maintain the uniformity of samples as match as possible. In order to investigate the relationship between the variety and its susceptibility to infestation, measurements of frond base width, depth, and weight were also recorded.

Data of these experiments were statically analyzed according to ANOVA test and differences between means were calculated according Duncan Multiple Range Test

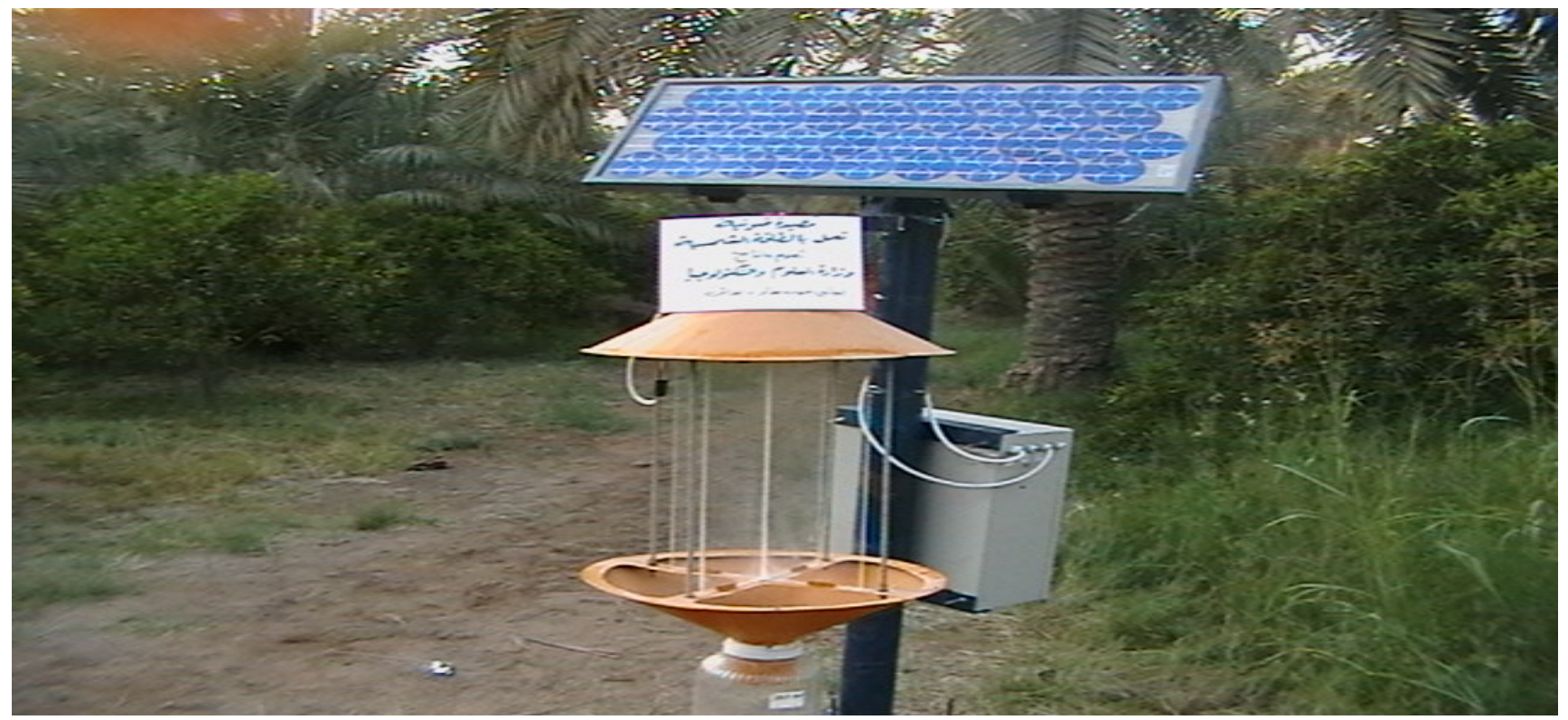

Fig.1.A locally designed solar insect light traps used to determine the population density of Oryctes elegans.

\section{RESULTS AND DISCUSSION}

Population density of O.elegans larvae: Results of the field studies indicated that the mean number of O.elegans larvae was 5.75 individual/tree reported in the part which was under annual cultural practices that was including pruning and removal of old dried fronds. The varieties Brim and Oastaomran were the most susceptible hosts with an average numbers of 12.7 and11.7 larvae /tree respectively. While the number of borer larvae was ranged between $3-4$ individuals / tree on other date palm varieties (Zahdi, Berhee, Khadhrawi, Khastawi, Oueedi, and Tebarzal ).Larvae were found feeding in holes and tunnel- like places appeared as a circular regions in the base of 
frond and between two close be fronds. Symptoms of infestation could be identified by the presence of feeding residues and debris .Old larvae and prepupae were found in places resembling nests of birds which was surrounded by small particles and degredated tissue materials from fronds bases (Fig.2).When larvae were placed in jars and taken to the laboratory for rearing and farther observations, they developed to light brown pupae in side the nestlike places (fig.3) then they were developed to adult stage (fig.4).Adults feeding sites and damages on bunches and on frond bases were obviously observed on infested trees.(fig.5).

Results of this surveying study could be used as a guide for farmer whom doing the annual cultural practice such as burning, cutting and removing of old dried leaves and frond bases. Borer larvae can be collected and destroyed to minimize the source of infestation for the next generation. This method can be applied as one of the cultural practices within a comprehensive date palm management system. Therefore, this method will help in monitoring the population density of larvae and infestation level along with maintaining a good tree health through a reliable sanitation program that would not have any adverse effects on date palm trees. Previous studies showed that determination of borer density can be done by cutting the trunk and removing of all leaves to collect the larvae found in any part of the tree (AlKhawaga, 1999), however this method would completely destroy the tree and that mean farther economic losses for orchards owners.

Population density of adultsO.elegans: Data presented in table (2) indicated that adult insects were readily attracted to light traps. The mean trap catch during the whole period of monitoring was 28.5 individuals /trap/month. The number of catches adults recorded during July 2009 was 30 individuals/trap increased during the subsequent months and reached to 37 insects/trap during September. After that a big decline was observed in the population density of adults with a mean trap catch of 14 insects/trap recorded during October of the same year. Results have also indicated that there is one generation for this insect per year which is similar to the results obtained in previous studies obtained by Swayir et.al.1979 and Harib1970.whom found one generation per year for $O$. elegans in Iraq and Iran.

Table 1.Population density of O.elegans larvae on deferent date palm varieties in orchards south of Baghdad during March and April 2009.

\begin{tabular}{|c|c|c|c|}
\hline \multicolumn{2}{|l|}{ No. } & Variety & \multicolumn{2}{|c|}{ No. larvae/tree } \\
\cline { 3 - 4 } & & Mean & $\begin{array}{c}\text { Slandered } \\
\text { deviation }\end{array}$ \\
\hline 1 & Brim & $12.7 \mathrm{a}$ & 3.40 \\
\hline 2 & Oustaomran & $11.7 \mathrm{a}$ & 3.10 \\
\hline 3 & Zahdi & $3.2 \mathrm{~b}$ & 1.40 \\
\hline 4 & Berhee & $3.3 \mathrm{~b}$ & 2.10 \\
\hline 5 & Khadhrawil & $4.2 \mathrm{~b}$ & 1.90 \\
\hline 6 & Khastawi & $3.6 \mathrm{~b}$ & 2.00 \\
\hline 7 & Oueedi & $3.4 \mathrm{~b}$ & 1.80 \\
\hline 8 & Tebarzel & $3.9 \mathrm{~b}$ & 2.20 \\
\hline Mean & & 5.75 & 2.24 \\
\hline
\end{tabular}

Means in same column with same letter are not significantly deferent according to Duncan multiple ranges tests.

Table 2.Number of O.elegans adults cached in the light traps during the period from July to October 2009

\begin{tabular}{|c|c|c|}
\hline No. & Month & No. Adults/trap \\
\hline $\mathbf{1}$ & July & 30 \\
\hline 2 & August & 33 \\
\hline 3 & September & 37 \\
\hline 4 & October & 14 \\
\hline & Mean & 28.5 \\
\hline
\end{tabular}
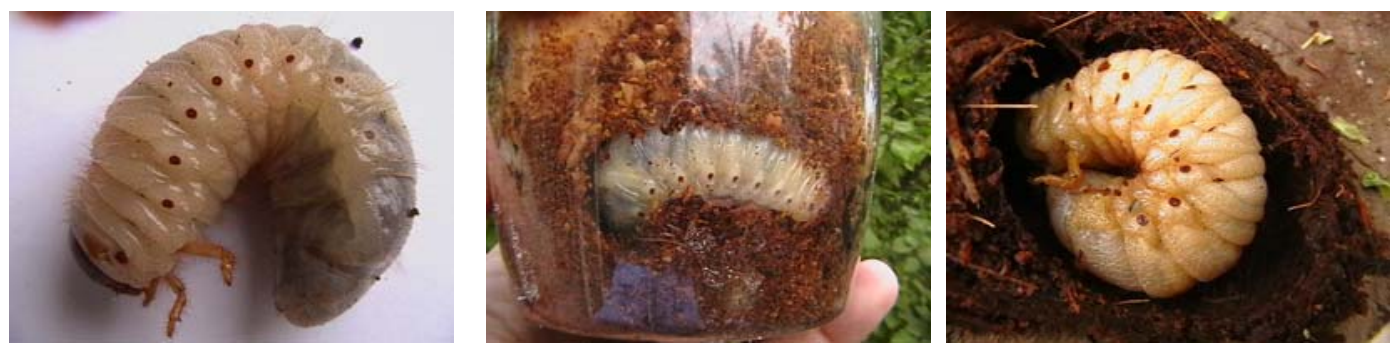

Fig.2. Larvae of O.elegans 
Agric. Biol. J. N. Am., 2010, 1(3): 238-242
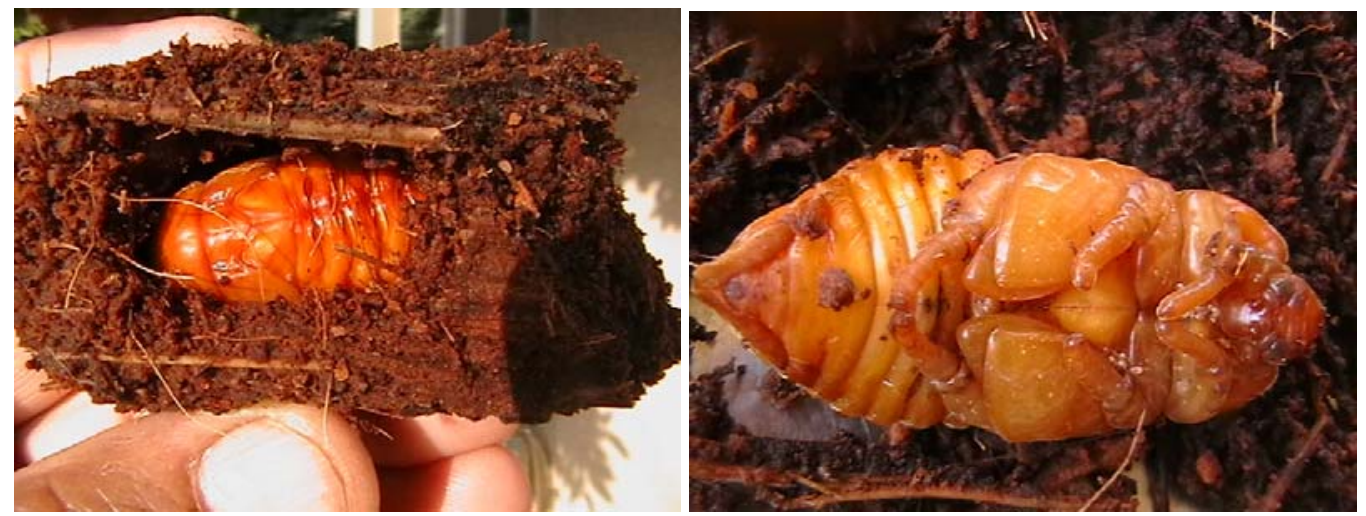

Fig.3.Pupae of O.elegans
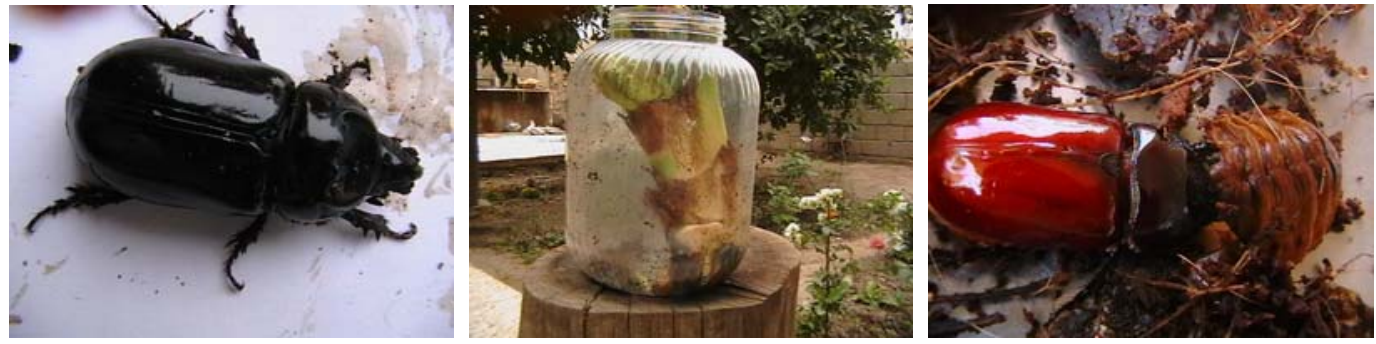

Fig.4.Adult emerging from pupae skin and adult of O.elegans

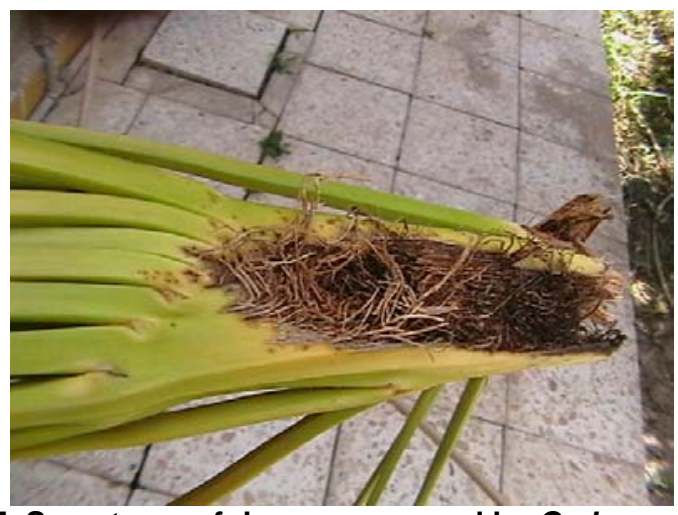

Fig.5. Symptoms of damages caused by O.elegans

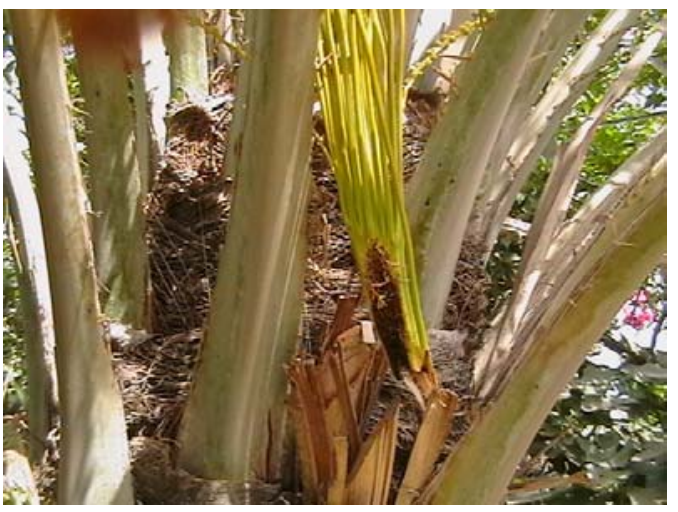

Morphological characters of frond bases for deferent experimental date palm varieties: Morphological studies of fronds bases showed an obvious variations between date palm varieties in term of width ,depth and weight of fronds bases (Table 3).The width and weight of fronds bases in Brim variety were $21 \mathrm{Cm}$. and $475 \mathrm{G}$. Respectively which were less than that recorded for other varieties. However the number of borer larvae collected from this variety was 12.7 individuals /tree. The widest and heaviest frond bases and the lowest number of larvae were, $29 \mathrm{Cm}, 1656 \mathrm{G}$ and 3.9 individual/tree respectively recorded for the variety Tebarzel. These characters could be attributed to the soft texture of frond base in Brim variety compared to the hardness and toughness of frond bases in Tebatzel variety . Since these characters are inherited for each variety, therefore, larvae preferred to feed on soft frond tissue and develop better than on varieties with tuff or hard textures. This negative correlation between texture and number of attracted and developed borer larvae need more investigation in the future studies in order to explore the chemical and nutritional components in each variety and to determine their relation to the susceptibility of cultivars to infestation. 
Results obtained from these experiments showed that the bunch stalk borer is an important pest attacking all varieties of date palm and it can be found in the field till October, however level of infestation and population density of larvae stages were varied depending on variety. Therefore this pest should be taken in consideration in any IPM regimes applied in the region. The following actions are very essential to asses the performance of date palm trees and improve date production. The first action is the enhancement of agricultural practices for managing date palm orchards and encouragement of sanitation program that would include cutting and burning of heavily infested trees or tree parts. Improvement of cultural practices for date palm orchards will certainly help growth vigor of trees to Table 3.Some morphological characters of frond bases and number of borer larvae in different date palm varieties:

\begin{tabular}{|c|c|c|c|c|}
\hline & $\begin{array}{c}\text { Frond base } \\
\text { widths } \mathbf{( C m )}\end{array}$ & $\begin{array}{c}\text { Frond base } \\
\text { depth } \\
\mathbf{( \mathbf { C m } )}\end{array}$ & $\begin{array}{c}\text { Frond base } \\
\text { weight (G) }\end{array}$ & Mean no. larvae/tree \\
\hline Bariety & 21.0 & 5.50 & 475 & 12.7 \\
\hline Oustaomran & 21.0 & 4.50 & 788 & 11.7 \\
\hline Berhee & 28.4 & 7.40 & 1318 & 3.3 \\
\hline Tebarzel & 29.6 & 7.75 & 1656 & 3.9 \\
\hline Zahdi & 26.4 & 7.60 & 1250 & 3.2 \\
\hline
\end{tabular}

\section{REFERENCES}

Al - Azawi, A.F.1986.A survey of insect pests of date palm in Qatar. Data Palm Journal..4(2): 247 -266.

Al- Bahely, A.Z.A. 2004.Study of biological and chemical control of date palm long horn stem borer.Jebusaea hammerscmidti Reiche (Cerambycidae :Coleoptera) M.Sc.Thesis.Coll.of Agric. Basra University.pp.90.

Al - Beker, A.J.1972.The date palm: A review of its past,present and recent advances in its culture industry and trade. Al- Watan Publ.Co.pp.1085.

Ali, H.A. and Al- Sandouk, N.M.2000.Field and laboratory observations on the biology of the palm tree stem borer Oryctes elegans (Coleoptera: Scarabaeidae).Iraqi J. Agric.5(3): 35-39.

Al-Jboory,I.J.;.Al-Sammariae, A.I.,Whaib, J.F and Ahmed, W.A.2001.Evaluation of Thiamithoxam in a different application techniques to control dubas bug Ommatissus binotasus lybicus (Debergevin). Arab J.PI.Prot.19(2):107 - 112.

Al- Khawaga, A.H.1999. Control of Oryctes elegans by cultural, biological and chemical means. Iraqi J.Agric.4 (1):20 -31.

Ba-Angood, S.A.;Al-Ghurabi,A.Sand, Hubaishan, M.A..2009.Biology and chemical control of the old world bug (dubas bug) Ommatissus lybicus DeBerg.on date palm trees in the coastal areas of Hadramout governarate, Repuplic of Yemen. Arab J. PI.Prot.27(1) ; $1-9$. withstand infestation. The second action is the development and establishment of reliable monitoring system to identify and map distribution of this pest and other date palm pests in general to be referred as a guide for any management practices in date palm orchards in the country.

\section{ACKNOWLEDGEMENTS}

The Authors are grateful to the International Center for Agricultural Research in the Dry Areas (ICARDA) $\&$ The International Fund for Agriculture Development (IFAD) . This work was supported by ICARDA \& IFAD , It is part from project" Improved livelihoods of small farmers in Iraq through integrated pest management and organic fertilization" \{ IRAQ - ICARDA - IFAD Project(IFAD GRANT NO. 1001 - 1Q)\}

Dhiab, I.M.Swayir I.A, and.Abdul-Hadi,I .1979.Investigation on palm -stem borer Pseudophilus testasceus Gah.(Coleoptera : Cerambycidae). Yearbook of Plant Protection .2(1):103 - 112.

Dowson, V.H.W.1982.Date production and protection with special references to North Africa and the Near East.FAO .Tech.Bull.No.35.pp 294.

Elwan, A.S.A.and Al-Tameimi, S.S.1999.Survey of the insect and mite pests as associated with date palm trees in Al- Dakhliya region .Sultanate of Oman. Egyptian J Agric.78:653 - 654 .

Harib, A.1970.Oryctes elegans .Entomophytopathology Appl.29:10 - 12.

Hussain, A.A.1963. Notes on borers' pf date palm in Iraq.Bull.Ent.Res.54: 345 - 348.

Hussein, A.A.1974. Date palms and dates with their pests in Iraq.Univ. of Baghdad.Ministry of High Education and Scientific Researches .Iraq, pp.166.

Martin, H.1968.Cereal and palm tree pests. Report to the Government of Iraq.FAO. Rome. Pub.no.233.

Swayir, I.A.;Dhaib, I.M and.Kadhum H ,1979.Investigations on palm fruit- bunch borer Oryctes elegans Prell.(Coleoptera : Dynastidae) .Yearbook of Plant Protection .2(1):97 - 102.

Zaid, A.2002. Date palm cultivation, FAO Plant Production and Protection. Paper NO. 156. pp.292. 